Türk Coğrafya Dergisi
Turkish Geographical Review
Www.tcd.org.tr

\title{
Milli parklar arasında farklı bir örnek: İstiklâl Yolu Tarihi Milli Parkı
}

\section{A different example between national parks:İstiklâl Road of Historical National Parks}

\author{
Nuran Taşlıgil*a \\ ${ }^{a}$ Marmara Üniversitesi, Fen - Edebiyat Fakültesi, Coğrafya Bölümü, istanbul.
}

ORCID: N.T. 0000-0003-2589-6045

\begin{tabular}{l} 
B I L G I / I N F O \\
\hline Geliş/Received: 06.02 .2020 \\
Kabul/Accepted: 29.05 .2020 \\
\hline Anahtar Kelimeler: \\
Milli park \\
Milli mücadele \\
Ulaşım \\
İstiklâl Yolu \\
İnebolu \\
Kastamonu \\
Çankırı \\
Keywords: \\
National Park \\
National Struggle \\
Transportation \\
Istiklâl Road \\
Inebolu \\
Kastamonu \\
Çankırı \\
\hline
\end{tabular}

*Sorumlu yazar/Corresponding author: (N. Taşlıgil)ntasligil@marmara.edu.tr

DOI: $10.17211 /$ tcd. 685542

\section{Atff/Citation:}

Taşlıgil, N . (2020). Milli parklar arasında farklı bir örnek: İstiklâl Yolu tarihi milli parkı. Türk Coğrafya Dergisi (74), 87-96. DOI: $10.17211 /$ tcd.685542

\begin{abstract}
ÖZ / ABSTRACT
Artan tabii ve kültürel değerlere yönelik koruma / koruma - kullanma bilinci ile çeşitli tedbirler alınmaktadır. Bunlar içerisinde ise milli parklar en geniş çaplı ve de kompleks koruma şekillerinden birisidir. Türkiye'de de bu anlamda kayda değer başarılar elde edilmiş olup 2020'ye gelindiğinde ülkedeki milli park sayısı 43 olmuştur. Bunlar içerisinde ise gerek tarihi, gerekse tabii şartlar bakımından en dikkat çekici ve de benzerlerinden farklı olanı, aynı zamanda Türkiye'nin en yeni milli parklarından İstiklâl Yolu Tarihi Milli Parkı'dır. Esasında tarihte çok önemli bir yer işgal eden İstiklâl Yolu, İnebolu Limanı'ndan başlayıp Ankara (Mamak)'daki askeri fabrikaya uzanan 344 km.'lik bir hatt ifade etmektedir. Milli Mücadele yıllarında söz konusu hat vasıtasıyla Kurtuluş Savaşı'nın en önemli lojistik desteği sağlanmıştır. Ayrıca yol boyunca gösterilen kahramanlıklar, gösterilen fedakarlıklar da söz konusu hatt sadece bir ulaşım hizmeti olmaktan çıkartıp manevi açıdan değerli bir ziyaret yeri haline getirmiştir. Kasım 2018'de milli park ilan edilen hattın geçmiş olduğu yerlerin turistik açıdan değerleri bir bütün halinde ele alındığında Türkiye'nin sayılı yerlerinden biri olduğu ortaya çıkmaktadır. Bu çalışmada da İstiklâl Yolu'nun tarihteki önemi, İnebolu'dan başlayarak milli park sınırları dahilinde turizme konu olabilecek değerler Turizm Coğrafyası prensipleri çerçevesinde ele alınmıştır.
\end{abstract}

Various precautions are taken with the awareness of protection / protection - use in the matter of increasing natural and cultural values. Among these, national parks are one of the most extensive and complex forms of protection. In this sense, either the remarkable successes have been obtained also in Turkey and the number of national parks in the country increased to 43 when came by 2020. Among them, both its history, and the most remarkable in terms of natural conditions and what is different from the like, Historical National Park of istiklâl Road is also one of Turkey's newest national park. In fact, Istiklal Road, which occupies a very important place in history, reperesents the line having the length of $344 \mathrm{~km}$. starting from Inebolu Port and reaching to the military factory in Ankara (Mamak). During the National Struggle years, the most important logistic support of the War of Independence was provided through the line in question. In addition, heroism and sacrifices shown along the way have made this line not only a transportation service but also a spiritually valuable place to visit. The line, declared as national park where it was installed by November 2018, is emerged that it is as one of the few places in Turkey when the point of touristic values taken as a whole. In this study, the importance of the istiklal Road in history, the values that may be subject to tourism within the boundaries of the national park are discussed within the framework of the principles of Tourism Geography starting from Inebolu.

\section{Giriş}

Özellikle 1800 'lerin ikinci yarısından itibaren, artan çevre kirliliği, Endüstri Devrimi'ne bağlı olumsuzlukların iyice belirginleşmesi, ozon tabakasının incelmesi gibi sayısı artırılabilecek pek çok husus çevre bilinci ve doğayla barışık yaşam konusuna daha fazla eğilinmesine neden olmuştur. Bir kısım sahaların önceleri tabii, sonraları hem tabii hem de beşeri yönleriyle korunması ve/veya korunup - kullanılması ise "Milli Park" uygulamasın gün- deme taşımıştr.Milli parklar; belirli büyüklüğe sahip biyolojik, coğrafik, jeolojik, morfolojik özellikler ve ve estetik bütünlük gösteren ve bunlarla birlikte uzun çağlardan beri şekillenmiş farklı kültürlerin izlerini taşıyan görüntü veren milli hatta milletlerarası değerlere sahip alanlar olarak tarif edilmektedir (Chapuis ve Lanneaux, 1993: 519). Bu anlamda dünyanın ilk milli parkı ABD'deki 1872 yılında ilan edilen Yellowstone olup 
kısa bir süre sonra 1889 'da Kanada'da Banff ve 1890 'da da Yosemite Ulusal Parkları doğmuş, Avrupa'da yaygınlaşması ise II. Dünya Savaşı'ndan sonra gerçekleşmiştir. Nitekim Fransa'daki ilk milli park, ABD'den çok sonraları 1963'te ilan edilmiş olan Vanoise'dir (Palaşoğlu, 1985: 16).

Ülkemizdeki milli ve milletlerarası düzeyde önemi haiz tabii, kültürel ve tarihi kaynak değerine sahip sahalar Tarım ve Orman Bakanlığı tarafindan "Milli Park" olarak ilan edilmek üzere tespit edilmekte, böylece bu değerleri koruma - kullanma dengesi içinde sürdürülebilir şekilde gelecek nesillere intikal ettirilmesi hedeflenmektedir. Türkiye'de milli parklar konusunda ilk yasal mevzuat 31.08.1956 yılında yürürlüğe giren 6831 Sayılı Orman Kanunu'nun 25. maddesidir. Kanun; “Orman Müdürlüğ̈̈’nün mevkii ve haiz olduğu hususiyetler dolayısıyla, lüzum göreceği ormanları, orman rejimine giren sahaların memleketin ilim hayatının istifadesine tahsis etmek, yurdun güzelliğini devam ettirmek, halkın çeşitli spor, dinlenme ihtiyacını karşılamak, turistik hareketlere imkan vermek maksadıyla 'Milli Park' olarak ayrılabileceği..." hükmüne bağlamış ve milli park uygulamasına imkan sağlamıştır. Bu doğrultuda da Türkiye'nin ilk milli parkı 1958 'de ilan edilen Yozgat Çamlığı Milli Parkı olmuştur.

1983 yılına kadar sadece ormanlık sahalar milli park kapsamındayken bu tarihte yürürlüğe giren 2873 Sayılı Milli Parklar Kanunu, orman dışında belirli özellikler taşıyan tüm sahaların milli park olabilmesi; bunun dışında Tabiat Parkı (229), Tabiat Anıt (114),Tabiat Koruma Alanı (30) ve daha küçük alanlarda değişik adlar altında muhafaza edilmesi kanunla belirlenmiştir. 2016 yılında Türkiye yüzölçümünün 7.9 milyon hektarı koruma alanı olarak ayrılmıştır. Bunun karasal alanlardaki kısmı 6.3 milyon ha. olup ülke yüzölçümünün \% 8'ine karşılık gelmektedir (Baykal, 2019: 373; Çevre ve Şehircilik Bakanlığı, 2016). 2873 Sayılı "Milli Parklar Kanunu" ile 4915 Sayılı "Kara Avcılığı Kanunu"na göre ilan edilip koruma altına alınan alanların Milli Park olarak sayısı 43 adet olup bunlardan en sonuncusu "İstiklâl Yolu Tarihi Milli Parkı"dır (Şekil 1).

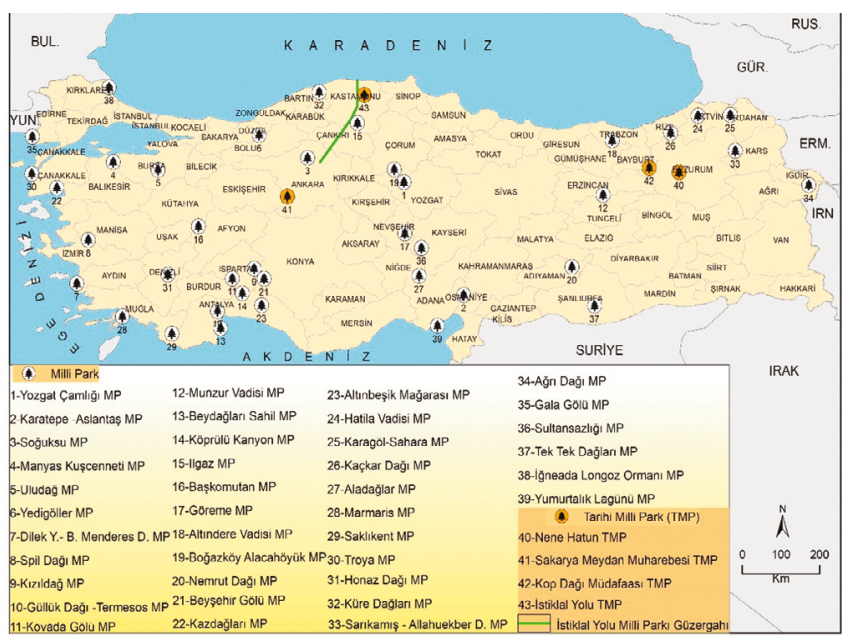

Şekil 1. Türkiye'deki Milli Parkların coğrafi dağılımı

Figure 1. Geopraphical distribution of National Parks in Turkey

İstiklâl Yolu Tarihi Milli Parkı ise en yeni koruma bölgelerinden birisidir. Park, esasında daha öncesinde de belli etaplarıyla koruma altına alınmıştır. İlk olarak İnebolu'dan başlayıp Küre veSeydiler'den geçerek Kastamonu - Merkez'e kadar devam eden yol (Yaklaşık 95 km.) Ankara 1 Numaralı Kültür Varlıklarını Koruma Bölge Kurulu tarafindan 2012 yılında "istiklâl Yolu" adıyla
Tarihi Sit Alanı olarak tescil edilmiştir. Daha sonra Ilgaz ilçesi İnköyü'nden başlayıp Ayan köyü ve Çankırı - Merkez ilçesine kadar devam eden yaklaşık 52 km.'lik kısmı yine Ankara 1 Numaralı Kültür Varlıklarını Koruma Bölge Kurulu tarafindan 2013 yılında "istiklâl Yolu" adıyla Tarihi Sit Alanı olarak tescil edilmiştir. Son olarak ise Cumhurbaşkanlığı'nın 01.11.2018 tarihli ve 302 Sayılı kararı ile "İstiklâl Yolu Tarihi Milli Parkı” olarak belirlenmiş ve 02.11.2018 tarihli 30583 Sayılı Resmi Gazetede yayınlanmıştır. Söz konusu milli park bu anlamda kapsamı, önemi ve de misyonuyla diğer milli parklardan çok farklıdır.

\section{Araştırma Sahası}

“istiklâl Yolu Tarihi Milli Parkı” diğer milli parklardan türlü özellikleriyle ayrılmaktadır. Araştırma sahamız olan "Yol - Ulaşım Hatt" temelli güzergah esasında İnebolu'dan Ankara'ya kadar olan tüm bir hatta içermemektedir (Şekil 2). İlk olarak 2012'deki İnebolu - Küre - Seydiler'den geçen Kastamonu merkezine kadar devam eden yaklaşık 95 km.'lik yol ile Ilgaz ilçesinin İnköy'den başlayıp Korgun ilçesinin arazisini takiben Ayan Köyü ve Çankırı - Merkez ilçesine kadar devam eden yaklaşık 52 km.'lik yol çalışma sahamızı oluşturmakta olup esasında iki parçalı bir koruma alanıdır. Aynı zamanda İstiklâl Yolu'nun Kastamonu yönünden itibaren 9.2 km.'lik kısmı Ilgaz Dağı Yaban Hayatı Geliştirme Sahası içinden, devamındaki 56 km.'lik "Ilgaz Dağı Milli Parkı”ndan geçmektedir. İstiklâl Yolu'nun koruma alanı içinden geçen kısmı 14.8 km.'dir. Bu açıdan esasında söz konusu saha Türkiye için pek çok özelliğiyle koruma altına alınmış sahalar bütünüdür de diyebiliriz.

İstiklal Yolu olarak adlandırılan güzergah 3 il, 7 ilçe, 21 köy olmak üzere toplam 31 yerleşim merkezi içinden veya yakınından geçen bir hattır. Yaklaşık 344 km.'lik yolun yarısı ise mevcut karayolunda kalmıştır. Milli park olarak belirlenen saha ise çok daha sınırlı bir alanı kapsamaktadır. Çankırı ve Kastamonu illeri sınırları içerisinde bulunan saha, 2873 Sayılı "Milli Parklar Kanunu"nun 3. Maddesi gereğince "İstiklâl Yolu Tarihi Milli Parkı" olarak 1 Kasım 2018 tarihinde Cumhurbaşkanı tarafindan onaylanmıştır. Tüm bu özellikleriyle çalışma sahamızı oluşturan İstiklâl Yolu Tarihi Milli Parkı, toplamda 236 ha. alanı kapsamaktadır.

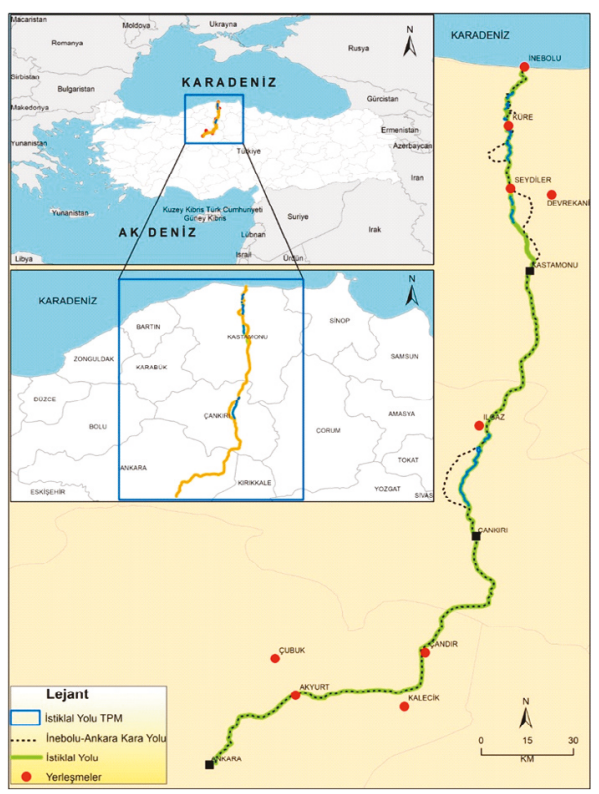

Şekil 2. Araştırma sahası lokasyonu ve İstiklâl Yolu güzergâhı Figure 2. Research area location and Istiklal Road route 


\section{Veri ve Yöntem}

Türkiye'nin en yeni Tarihi Milli Parkı olan İstiklal Yolu Tarihi Milli Parkı, sayısallaştrılarak ilgili görselleri ArcGis 10.7 programında hazırlanmıştır. Güncel uydu görüntüleri, Google Earth ve Open Street Map ile Kültür ve Turizm Bakanlı verilerinden yararlanılarak milli parkın güzergahı ile çevresindeki önemli turizm alanları belirlenmiştir. Yerleşim yerleri, ulaşım güzergahları, milli parklar ile önemli turizm merkezleri ve diğer coğrafi veriler Google Earth veri tabanında tanımlanarak KML dosyası olarak oluşturulmuştur. Bu dosya önce ArcGIS ortamında shapefile (shp) formatına dönüştürülmüştür. Sahada 2019 yılında arazi gözlemleri yapılarak destinasyon alanları, başlıca çevre düzenlenmesi ve restorasyon gerektiren yapılar ile güzergah boyunca yer olan tarihi ve kültürel alanlar tespit edilmiş ve güncel durumları değerlendirilmiştir.

\section{Tarihi Açıdan İstiklâl Yolu}

Ulaşım, medeniyetin gelişip şekillenmesinde en önemli ve de birincil unsur olarak her zaman toplumların, devletlerin, hükümetlerin en fazla üzerinde durduğu konuların başında yer almıştır. Ulaşımın gelişmişliği bir açıdan da medenileşme, medeniyetin gelişmesi ile bir tutulmuştur. Anadolu şartlarında da medeniyetin gelişmeye başlayıp etki alanını çok geniş bir alana yayması doğal yollar ve çok daha sonraları "Roma Yolları" ile mümkün olmuştur. Ticaret, savaşlar, turizm, endüstri - hammadde ilişkisi gibi sayısı artırılabilecek devletler için hayati faktörlerde ulaşım başrolü oynamıştır. Buna karşılık Türkiye'de genel manada ulaşım yakın yıllara değin istenilen seviyeye çekilebilmiş değildir. Çoğu Beylikler Dönemi'nde yapılmış Anadolu'daki karayolları, Osmanlı İmparatorluğu'nda da uzun yıllar kullanılmış, devletin zayıflamasıyla bakımsız kalmıştır. Sonraları denizyolları da tercih edilmeye başlanmış, bu yüzden de limanlardan Anadolu içlerine uzanan yollar önem kazanmıştır (Taşlıgil, 2010: 134). Özellikle de limanların demiryolu hatlarıyla iç kesimlere bağlantısının sağlanması, hem beşeri hem de iktisadi anlamda ulaşım hatları ve bu hatların etki alanlarında büyük değişimler yaratmıştır.

Avrupa'da modern anlamda karayolu taşımacılığı gelişmeye başlayınca Osmanlı İmparatorluğu da karayolu yapımı ve bakımını düzenlemek için girişimlerde bulunmaya başlamıştır. Nitekim 1800'lerin sonlarına değin Osmanlı İmparatorluğu karayolu taşımacılığına fazla önem vermemiştir. Özellikle 19. yy.'ın ikinci yarısından itibaren İmparatorluk sınırları dahilinde önemli merkezleri birbirine bağlamak adına birtakım uygulamalar başlamış, bu kapsamda da erkek nüfusun her sene birkaç gün fiilen yol inşasında çalışması veya vergi vermesi yoluna gidilmiştir (Yılmaz, 1989: 102). 1866 yılında "Turuk ve Meabir Nizamnamesi Nizamname" ile yapılan düzenlemeyle ülkede mevcut karayolları Avrupa-i Osmani ve Asya-i Osmani adlarıyla ikiye ayrılmıştır (Çiçek, 1997: 399). Bu kapsamda da İnebolu Ankara Yolu: 8 olarak numaralandırılmıştır. Bahis konusu bu yol ilerleyen yıllarda ülke ve Türk milleti adına çok stratejik bir rol üstlenerek ulaşım konusunun önemini bir kez daha ortaya koymuştur.

İnebolu - Ankara Yolunun gelişimine baktı̆ımızda; Kastamonu Valisi Sırrı Paşa (1844 - 1895), İnebolu Limanı vasıtasıyla İç Anadolu'yu Karadeniz'e açmaya çalışmış,aynı zamanda hinterlandın potansiyelleri ile yöre iktisadi hayatını canlandırmayı hedeflemiştir. Bunun için de Çankırı'daki mevcut kaya tuzu ile vilayetin fazla zahiresini katır kervanları ve arabaları ile İnebolu'dan yurtdışına gönderilebilmesi için Çankırı - İnebolu arasında karayolu ile İnebolu'ya bir liman planlanmıştır. O zamana kadar liman olmadığı için iç kısımlardan gelen yük ve yolcu, İnebolu'da çekek yerlerindeki kayıklara bindirilerek demir yerindeki gemilere taşınırdı. Buna bağlı olarak da İnebolu kıyısında kayıkçılık oldukça gelişmiş olup İnebolu'nun başlıca kültürel miraslarından biri olan "Denk Kayıkları" da günümüze değin ulaşabilmişlerdir.

Çankırı - İnebolu arasında cepli makadam yol ${ }^{1}$ planlandığı gibi yapılmıştır. Limana gelince, aslında Küre kömürlerini işleten Fransızlar, Fener Burnu'nun ucundan denize doğru uzanan bir mendirekle İnebolu'ya küçük bir barınak yapmışlardı. Vali Sırrı Paşa, bu mendireğin karayele bakan kısmına biraz daha ilave yaptırarak sahile paralel ikinci bir mendirek planlamış ve 1882'de de inşaatına başlanmıştır (Eski, 1997: 929). Sırrı Paşa tarafindan yaptirılan planda Patriyos Koyunu, İskelle Burnu'na kadar içine alacak şekilde poyraz istikametinde uzatlacak ve İskelle Burnu'ndan denize doğru yapılacak bir dalgakıranla liman tamamlanacaktı (Çiçek, 1997: 399).

Liman yapımına başlandıktan kısa süre sonra Sırrı Paşa'nın yerine Abdullah Galib Paşa (1828 - 1903) atanır. Paşa, bitirilen yolun cep ilavelerini tamamlatır. İlk etapta Çankırı kaya tuzu, Çankırı ve Kastamonu zahiresi ve kerestesi katır kervanları, manda ve at arabalarıyla İnebolu'ya gelmeye başlar. Yolun bitiminden sonra Paşa, limanı plan gereği doğuya yani poyraza doğru uzatılacak yeni kısmın ilk bölümünü (Yaklaşık $115 \mathrm{~m}$.) ve arka dolgularını tamamlatmıştır (Eğdirici, 2014: 39). Kuzey ve batıdan esen rüzgarda küçük tonajlı gemiler yeni yapılan bu barınak içinde firtınalı havalarda korunurlardı. Yüklerini de yine buradan alırlardı. Yolcuların barınak yerinden kayık veya motora binerek açıkta demirleyen (Alarga) vapura gidiş ve gelişleri özellikle de firtınalı havalarda kayıkçıların cesareti ile gerçekleşirdi.

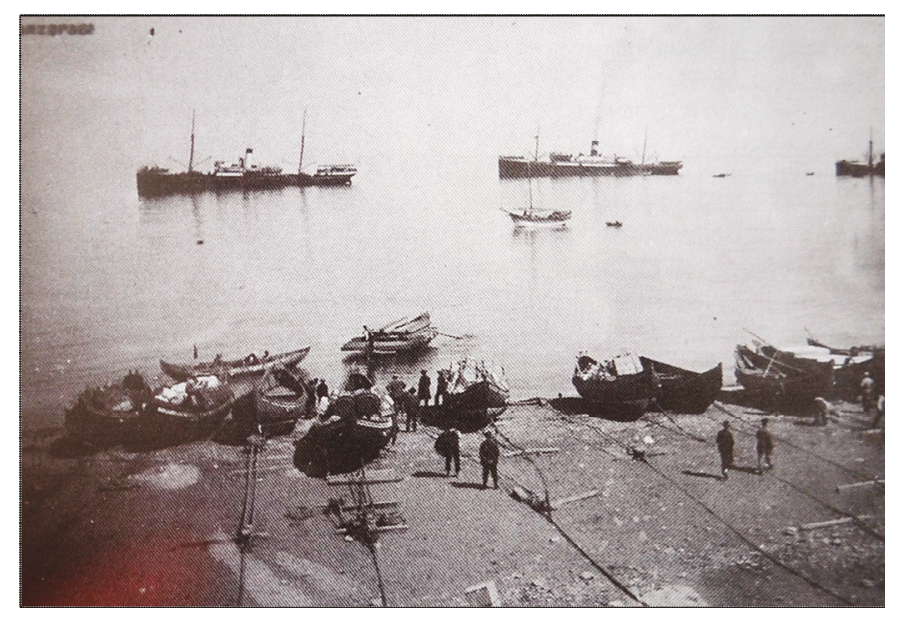

Fotoğraf 1. İstiklâl Yolu'nun Başlangıcı ve En Önemli Noktası Olan İnebolu Kıyılarında Açıkta Bekleyen Gemilerle Bağlantıyı Sağlayan Denk Kayıkları (Fakazlı, 2006).

Photo 1. Equivalent Boats Providing Connectionwith the Waiting Ships in the Inebolu Shores, the Beginning and the Most Important Point of the Istiklal Road (Fakazlı, 2006)

${ }^{1}$ Makadam Yol: Taş ocağı kumu ile 4-7 cm. iriliğindeki kırma taşlarla kaplanmış ve silindirlenmiş yol. Ufalanmış ve sıkıştrılmış taş döşeli yol. 
I. Dünya Savaşı süresince İstanbul'un yiyecek ve gıda ihtiyacının artması üzerine bu bölgeden İstanbul'a önemli ölçüde gıda sevkiyatının başlamasıyla bazı köprülerin onarımı ve güzergâhların yapım çalışmalarına ağırlık verildiği görülse de pek başarı sağlanamamıştır (Çiçek, 1997: 399). Vilayet tarafindan ihaleye çıkartılan köprü işleri yeterince para sağlanamadığından ve talep olmadığı için de bitirilememiştir. Yine I. Dünya Savaşı'nda Macarlar, İnebolu'da bir liman yapımı konusuyla ilgilenmiş, özellikle de çevredeki kaynakların (Küre madeni ve kereste gibi) kolay bir şekilde nakliyesine yönelik planlamalara girişmişlerdir (Eski, 1997: 936). 1926'ya gelindiğinde mendirek yıkılmış, 1975'e kadar da İnebolu Limanı'nda aralıklarla çeşitli tamiratlar ve eklentiler (Tali mendirek, balıkçı rıhtımı gibi) yapılmıştır.

Milli Mücadele'nin başlangıcında İnebolu - Ankara Yolu; bakımsız, çoğu yerde köprüleri yıkılmış ve motorlu taşıtların geçişlerine elverişsiz bir haldeydi. Ankara'da Milli Hükümet kurulduktan sonra o tarihe kadar çeşitli yollardan Anadolu'ya gönderilen silah ve cephane Nisan 1920 tarihinden itibaren İngilizlerin, Kocaeli ve çevresine askeri müfrezeler yerleştirmesiyle yavaş yavaş sevkiyat Karadeniz'e kaymaya başlamış, buna bağlı olarak İnebolu - Ankara Yolu da önem kazanmıştır. 1920'lerde Anadolu'nun çeşitli yerlerinde çıkan isyanlar, Samsun - Ankara Yolu'nun zaman zaman Pontus çetelerinin baskınına uğraması yüzünden bu yol 1920 ve 1921'in başlarında kullanılmamıştır.

1920 yılında Karadeniz üzerinden yoğunlaşan silah sevkiyatı sadece İstanbul'dan kaynaklanmıyor, Doğu Cephesinden ve özellikle Sivastopol,Novorossisk, Tuapse ve Batum limanlarından da geliyordu (Anonim, 2017: 9). Getirilen lojistik malzeme ve mühimmat İnebolu'ya has "Denk Kayıkları” ile limana taşınmaktaydı2. Inebolu'ya ilk yardım 28 Ağustos 1920 tarihinde gelmiştir.

İnebolu - Ankara Yolu, coğrafi olarak zorlu bir güzergâhtan oluşuyordu. Limandan başlayan yol kasabaya bir saatlik mesafede İkiçay Deresi civarında kontrol karakolunda mola veriyordu. Bahis konusu karakol, sevkiyatn kontrolü, denetimi ve asayişin sağlanması için yol üzerinde kurulan karakolların birincisiydi. Diğerleri ise Derbent (Ilgaz Dağı), Gündoğdu (Doğdu) ve Töney (Tüney) Jandarma Karakolları idi. İkiçay Jandarma Karakolu'nda son kontroller yapıldıktan sonra kağnı kolu Kastamonu'ya doğru yola çıkıyordu. Bu yolun ilk durağı ise Küre idi. Subay ve askeri personel ile aileleri burada askerlik şubesinin misafirhanesinde konaklıyorlardı. İkinci durak da Seydiler'di (Çiçek, 1997: 401).

İnebolu - Kastamonu Yolu, kağnı kolu ile 6 gün sürüyor, 1 kağnı kolu da 40 - 50 kağnıdan meydana gelmekte ve kağnı kolundakiler 50 - 60 yaşın üzerindeki erkekler, $14-18$ yaşındaki erkek çocuklar ve büyük çoğunlukla da kadınlardan oluşmaktaydı. Her bir kağnı başına 25 lira ile yol boyunca ihtiyaç duyacağı gıda masrafi verilmiştir. Kağnı kolları askeri malzeme taşıdıkları için her birinin başında 1-2 jandarma eri ile bir zabit bulunuyordu.

Kağnı kollarının 6 günlük durakları;

1. Gün: Digüz Köyü yakınındaki Soğuksu Hanı

2. Gün: Küre Nahiyesi

${ }^{2}$ Denk Kayıkları: Yapım tekniği ile dünyada bilinen başka bir benzeri bulunmayan karakteristik bu kayıklar, İnebolu'nun gelişip önemli bir merkez olmasında ve de en önemlisi Milli Mücadele'de çok büyük rol oynamışlardır.

\section{Gün: Ecevit \\ 4. Gün: Seydiler Köyü}

5. Gün: Sırasöğütler

6.Gün: Kağnı kolları Kastamonu'ya varmak zorunda idi.

İnebolu - Kastamonu - Ankara hatt, İstiklâl Savaşı́nın başından itibaren cephe gerisindeki en önemli lojistik yol olup önemi mücadele süresince devam etmiştir. Bu yoldan Batı Cephesi'ndeki savaşın kaderini etkileyecek kadar silah ve cephane taşınmıştır. Bu silah ve cephaneler, vatanın kurtuluşu için kadınlar ve gençler silah altında olduğundan ekseri yaşlılar tarafindan taşınmıştr. Gazi Mustafa Kemal, bunun bilincinde olduğu için bu hassas durumu "Gözüm Sakarya'da, Dumlupınar'da; kulağım Inebo$l u^{\prime} d a^{\prime \prime}$ veciz sözleriyle ifade etmiştir.

Mondros Mütarekesi'nden sonra İnebolu İskelesi, Ankara'ya en yakın ikmal üssü haline geldiğinden Ağustos 1920'de “Yükleme ve Boşaltma Komutanlığı" kurulmuş ve ilk yardım 28 Ağustos 1920 tarihinde gelmiştir (Anonim, 2017: 12). Önce İstanbul'dan kaçırılan daha sonra Ruslarla imzalanan anlaşmayı takiben Doğu Karadeniz'den ve Rusya'dan gelen silah ve cephaneler Şube deposuna ve çarşıdaki ambarlara doldurulmaya başlanmıştır. 1 Haziran 1921'de 2 vapur üst üste İnebolu'ya gelip art arda cephaneleri boşaltmışlardır. Bahis konusu malzemeler denizden görülmeyecek biçimde şehrin çarşısındaki taş mağazaların arka taraflarına istiflenmiş, kilim, muşamba gibi malzemelerle örtülmüşlerdir. İnebolu'nun içi adeta bir cephane deposuna dönmüştür. Hatta mevcut yapılar yetmeyince İkiçay mevkiinde araziye kurulan çadır ve barakalara taşınmıştır. Ankara Hükümeti ile Ruslar arasında yapılan anlaşmadan sonra Ruslar sandıklar içinde bir miktar altın para da göndermişlerdir. Birinci kısım Trabzon'dan Inebolu'ya, ikinci parti ise 2 Rus denizaltısı tarafindan İnebolu'ya getirilmiş, denizalt limanın içine kadar sokularak altın sandıkları çıkarmışlar ve bu yolla Ankara'ya gönderilmiştir.Fakat ilçedeki Rumların şikayeti üzerine 2 Haziran 1921'de bir Yunan savaş gemisi İnebolu önlerine gelmiş ve kıyıya yaklaşmıştır. Ancak denizden bakıldığında herhangi bir şey görülmediği için gitmiştir. Silah ve cephaneler İnebolu'ya gelmeye devam ederken 9 Haziran 1921 Perşembe bayram sabahı saat 05.00 'te biri Averof Kruvazörü olmak üzere, 2 Yunan gemisi (Averof) İnebolu'ya gelerek ültimatom vermişlerdir. Canını kurtarmak isteyen halk ilçeden uzaklaşırken taşıyabilecekleri kadar silah ve cephaneyi beraberlerinde götürmüşlerdir. Hem sabah hem öğle saatlerinde yaptıkları bombardımanda sahildeki kayıklar ile şehirde ufak tefek hasarlar meydana gelmiştir. Daha sonra da 30 Temmuz 1921'de de Kılkış Zırhlısı ile 2 Yunan torpidosu İnebolu önlerine gelerek bir müddet dolaşmışlar ve batıya doğru giderken 3 adet gülle atmışlar; bunların ikisi cephanelerin bulunduğu İkiçay Deresi'ne, biri de tarlaya düşerek patlamış, herhangi bir zarar vermemiştir.

Genel olarak İstiklâl Yolu, patika ve kağnı yolları olarak adlandırılan zorlu bir hattır. Yolun Kastamonu ilindeki kesimi, deniz seviyesinden başlayıp Ilgaz Dağı'nda 1.875 m. yüksekliğe çıkmaktadır. Yolun Çankırı ilindeki kısmı 107 km. olup Ilgaz Dağı'nda 1.875 m.'den başlayıp Ankara il sınırları içinde 755 m.'ye inmektedir. Ankara ili içinde 103 km.'lik kısım 755 m.'den başlayıp Ankara - Solfasol Köyü'nden sonra Askeri Fabrika (Mamak)'da (860 m.) sonlanmaktadır (Şekil 3).O tarihte kağnılarla silah ve mühimmat taşınırken milli orduya katılmak isteyen subaylarla, Ankara Hükümeti ile bağlantılı olan yerli ve yabancıların hepsi bu yolu kullanmakta idiler.Yolcuların yaylı araba- 
larla yolculukları 8-10 gün sürmekteydi.

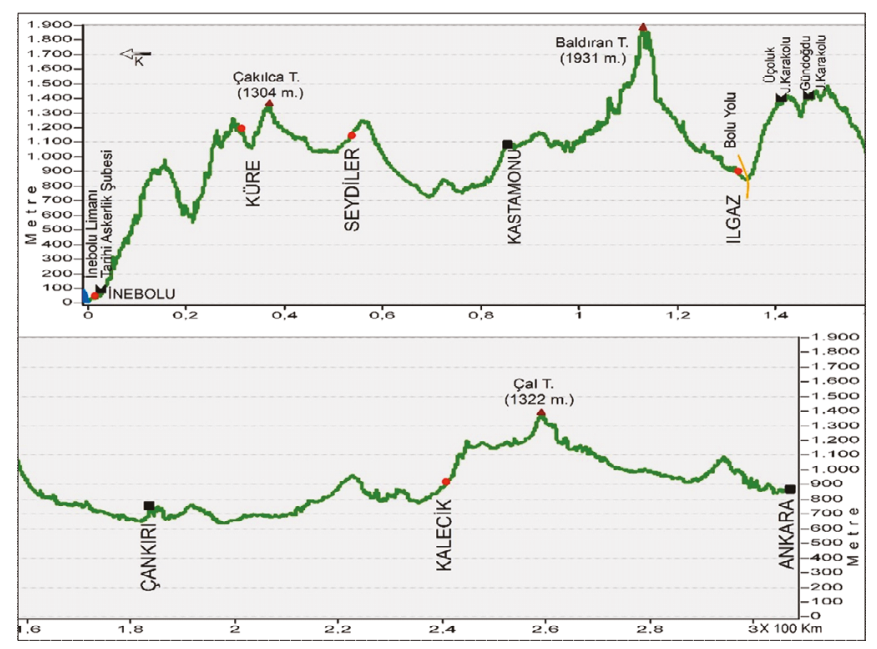

Şekil 3. İstiklâl Yolu'nun profili ve önemli noktaları

Figure 3. Profile and highlights of the Istiklal Road

Kastamonu - Çankırı Yolu yaylı araba ile 3 günde katediliyordu. Kağnı kolları Kovanlı, Bulacık, Umut, Kayı, Beşdeğirmenler, Gülmenler Köyü, Güngörmezler, Hacetepe, Bostan Köyü, Çomar, Yenice, Kalehan, İnköyü, Koçhisar, Kese Köyü'nden sonra Çankırı'ya ulaşıyorlardı. Çankırı - Ankara arasında ise Avran Köyü, Dümbelek Ovası, Tüney Köyü, Çandarlı, Kalecik, Yenihan, Tekebeli, Ravlı, Bödüz, Ballı, Hüseyin, Solfasol köylerinde konaklayarak Ankara'ya ulaşmakta idiler. Ankara'da da Mamak'taki Askeri Fabrika son durağı teşkil ediyordu.

Yolun en zor kesimi İnebolu'nun İkiçay mevkiinden Çatalçeşme'ye kadar olan Topçuoğlu, Kayıncak, Küre, Ecevit yokuşlarıdır. Yokuşun başına gelindiğinde arabalar tek başına çıkamadığından arkasından gelen arabadan çıkartılan bir çift öküz öndeki arabaya ilave edilerek yokuşların çıkılması sağlanıyor, böylece birbirlerine yardım ederek engeller aşılıyordu. Her gün çok sayıda araba (200 civarında) yola çıkıyordu.

İstiklal Savaşı́nın başından sonuna kadar bir lonca halinde çaIışan İnebolu kayıkçılarının kahramanlıkları, savaşın ardından T.B.M.M. tarafindan unutulmamış, 11 Şubat 1924 tarihindeki 99. oturumda İnebolu'ya "Beyaz Şeritli İstiklâl Madalyası ve Beratı" verilmesi kararlaştırılmıştır. Tertiplenen bir törenle Kayıkçılar Loncası adına Kahya Sovangözoğlu'na verilmiştir. Böylece İnebolu, Atatürk imzası taşıyan Beyaz Şeritli İstiklâl Madalyası'nı alan ilk ve tek ilçe olmuştur. Bu yolun önemi ve halkın fedakârlığı Fransız siyaset adamı Frank Bouillon tarafindan "Kağnı kamyonu yendi..." ifadeleriyle uluslararası kamuoyuna dahi taşınmıştır. İnebolu'da da bu başarı hala hafizalarda yer etmekte "inebolu kayıkla kağnının mucize yarattı̆ı beldedir." ifadesi ile anılmaktadır.

T.B.M.M. hükümeti Mart 1921 yılında bir kanun çıkartarak bütün yolların yapım ve onarım işleri için "Tarik-i Bedelat-ı Nakdiyesi" mükellefiyeti getirmiştir. Buna göre 18 - 60 yaşları arasında olup da silah altinda bulunmayan herkes 4 amele yevmiyesi ödeyecekti. Kastamonu Vilayet Meclisi, Ankara - Inebolu Yolu'nun yapım ve onarım işlerinde Nafia Vekaletince oluşturulan Amele Taburları'nın kullanılmasına karar vermiştir.Zira yolun sürekli kullanıma açık tutulması zorunlu idi. Ayrıca Vekalet, bu yolun bakımı için özel bir tahsisat ayırmıştır. İneboluAnkara Yolu'nun 135 kilometresi Kastamonu sınırları içinde bu- lunmakta olup 1921 - 1922 yıllarında yol bakım ve onarımı $3.500 \mathrm{~m}^{3 \prime}$ lük taş kırılarak tamirat yapıldığı özellikle kamyonlar bu yolu kullanmaya başlayınca da şose ve bazı köprülerin bu vasıtalar tarafindan tahrip edildiği başmühendis tarafindan ifade edilmiştir (Çiçek, 1997: 410). Nafia Vekaleti'ne bağlı 2 amele taburu yolun Kastamonu sınırları içinde kalan kısmında devamlı tamirat işleri ile uğraşmıştır.

Yolun Türkiye Cumhuriyeti tarihindeki önemi ve Misak-ı Milli sınırları içerisinde yaşanan pek çok kahramanlık öykülerinden birkaçı da bu hat üzerinde cereyan etmiştir. Bu anlamda söz konusu milli parkın manevi açıdan değerinin de net bir şekilde anlaşılması için bu kahramanlıklarında izahı gerekmektedir.

Şehit Şerife Bacı, Halime Çavuş ve Ersizlerdere: Erzurum özelinden tüm Türkiye'ye mal olmuş olan Nene Hatun (1857 1955) gibi İnebolu - Ankara / İstiklâl Yolu ile özdeşleşmiş ve de sembol bir değer halini almış olan bir diğer kadın kahraman da Şerife Bacı'dır. Şerife Bacı 1900 yılında Seydiler'de doğmuştur. 16 yaşındayken evlendirilmiş olan Şerife Bacı'nın 2 ay sonra kocası askere alınmıştır. Ne yazık ki 6 ay sonra da Çanakkale'den kocasının ölüm teskeresi gelmiştir. Kimsesiz ve hiçbir geliri olmayan Şerife Bacı, bir gazi ile evlendirilir. 1921'in başlarında köyde kağnısı olanların cephane taşımak üzere İnebolu'ya gitmeleri için duyuru yapılınca kağnısıyla İnebolu'ya gitmeye karar verir. 9 aylık kızını da yanına alarak soğuk bir kış gününde kafileye katilır. İnebolu'dan cephaneyi alarak yola koyulur. Kafile yoğun bir kar yağışına yakalanır. Şubat ayı karlı tepeleri yaya aşmak hiç de kolay değildir. Bir süre sonra Şerife Bacı kafilenin arkasında kalır. Dinlenmedikleri için ağır ilerlemektedirler. Hava kararmış ve tipi de hızlanmıştır. Yorganıyla cephanesini örter, yavrusunu da güllelerin altındaki kurumuş ot ve samanlardan bir yatak yaparak onların arasına yerleştirir. Tipi şiddetlenmiş, yürüyecek gücü de kalmamıştır. Ertesi gün sabaha karşı askerler Kastamonu kışlasına yakın bir yerde cephanenin üzerine kapaklanmış bir halde bulurlar. Şerife Bacı şehit olurken geriye ıslanmasın diye üstü yorganla örtülü top mermileriyle kuru otların arasında ağlayan küçük kızını bırakmıştır. Kışlaya getirilen genç kadının hüviyeti tespit edilerek köyü olan Seydiler'e gömülür. Şehit Şerife Bacı adına yakın yıllarda Korgeneral Aytaç Yalman'ın katkılarıyla İnebolu'da bir anıt dikilmiştir.Ayrıca 2019'da da Şehit Şerife Bacı adına İstiklâl Koşusu yapılmıştır.

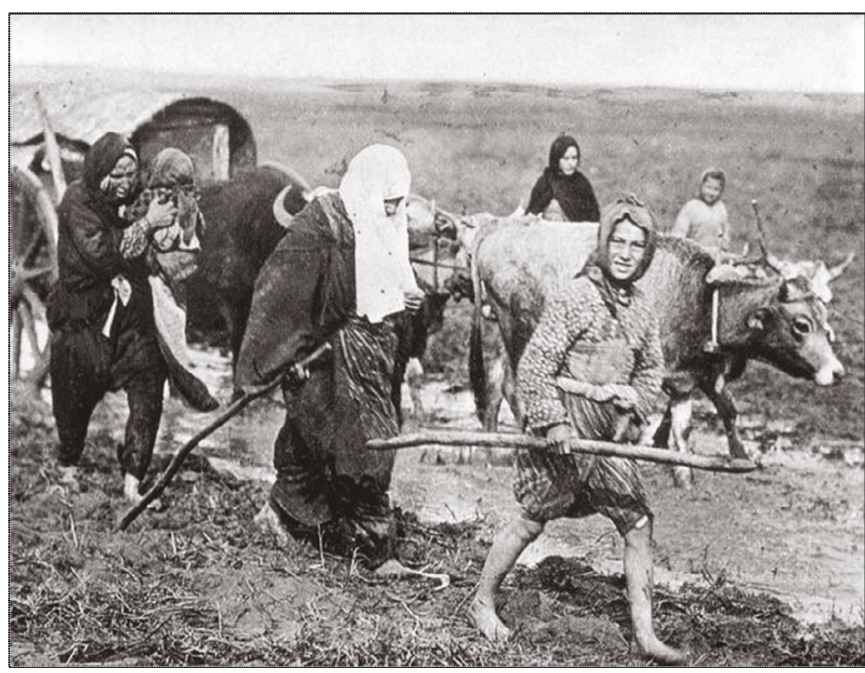

Fotoğraf 2. İstiklâl Yolu'nda cephane taşıyan pek çok isimsiz kahramandan olu şan konvoydan bir görünüm

Photo 2. A view from a convoy of many unnamed heroes carrying ammunution on the Istiklal Road. 
Burada Şehit Şerife Bacı yanı sıra Duruçay (Kastamonu / Merkez)'dan Halime Çavuşu da zikretmek gerekir. Halime (Kocabıyık) Çavuş (1898 - 1976), Milli Mücadele'nin simgeleşmiş bir diğer kadın kahramanlarından olup savaş müddetince uzun süre erkek kılığında büyük kahramanlıklar göstermiştir. 9 Haziran 1921 tarihinde İnebolu bombardıman edilirken de şarapnel parçasıyla ayağından yaralanmış ve ordudaki aktif görevinden ayrılmak durumunda kalmıştır ${ }^{3}$. Gösterdiği üstün hizmetlerden ötürü bizzat Gazi Mustafa Kemal Atatürk tarafindan Çankaya Köşkü’nde İstiklal Madalyası ile onurlandırılmıştır.

Bu yolla ilgili bir diğer gerçek de İstiklâl Yolu üzerindeki Dereköy ile ilgilidir. Kastamonu'nun Küre ilçesine bağıı bu köyün kahramanlığından ayrıca bahsetmek gerekir. Kurtuluş Savaşı'nda köyde yaşayan erkeklerin hepsi cepheye gider, savaş sonrasında gidenlerin hiç birisi dönmez, nitekim her biri şehit olmuştur. Hiçbir erkek kalmadığı için Cumhuriyet'in ilk yıllarından buyana Ersizlerdere olarak anılmaya başlanır.

\section{Milli Park Sınırları İçindeki Tarihi - Doğal ve Kültürel Çekicilikler}

Araştırma sahamızı oluşturan İstiklâl Yolu Tarihi Milli Parkı; Kastamonu ve Çankırı illeri sınırlarını kapsamakta olup söz konusu iller esasında turizm açısından büyük atılım gösterememiş yerlerdir. Bu açıdan tek başına bu illerimiz ve bu illerdeki bugün için çekiciliği zayıf destinasyon sahaları yol aracılığıyla birleştirilerek önemli bir turistik hat oluşturulabilir. Yaklaşık 100 yıl önce Kurtuluş Savaşı'nın kazanılmasında önemli bir rolü olan İstiklâl Yolu'ndan günümüze kalanlar (Beşeri, Tarihi unsurlar) ise son derece sınırlıdır. Yolun çevresindeki diğer çekiciliklerin büyük bir kısmı da henüz yeteri kadar tanıtlamamış ve turistik altyapıdan büyük ölçüde yoksun alanlardır. Milli parkın sınırlarına girdiği illerdeki çekicilikleri ayrı ayrı ele alacak olursak;

\section{a. Doğal Çekicilikler:}

İstiklâl Yolu Tarihi Milli Parkı kapladığı alan itibariyle iki milli parkla adeta iç içedir. Bunlar 1976'da ilan edilen Ilgaz Dağı Milli Parkı ve 2000'de ilan edilen Küre Dağları Milli Parkı'dır. Bunlardan Küre Dağları Milli Parkı, aynı zamanda 2012'de PAN Parks (Avrupa'nın Seçkin Milli Parkları Ağı) üyesi ilan edilmiştir. Söz konusu parklar doğal çekicilikleri açısından olduğu kadar kültürel varlıklarıyla da önemli cazibe merkezleri olarak öne çıkmaktadır. Her iki park da topografik, klimatolojik ve ekolojik bakımdan dünyanın sayılı noktaları arasında gösterilmektedir.

Ilgaz Dağları́nın eğim durumu ve klimatolojik faktörler özellikle kış sporları bakımından büyük avantaj sağlamaktadır. Ilgaz Dağı Milli Parkı'nda sahanın \% 88.3 gibi kayda değer eğim durumu kayak pisti yapmaya elverişli olduğunu göstermiştir (Aydınözü ve ark., 2012: 118). Söz konusu bu dağlık kütlenin sağladığı kış sporları ve buna bağı ı kş turizmi avantajı yanı sıra planlı 2 yürüyüş parkuru bulunmaktadır. Yöre topografyasının sunduğu bir diğer önemli çekicilikler de kanyonlardır.Bu noktada da Ersizlerdere Kanyonu akla ilk gelenlerden birisidir.Yolun İnebolu - Küre arası İsfendiyar Dağlarını aşmaktadır. Bu yol üzerinde Ersizlerdere çıkışı, kanyonun güney çıkışı olup manzarası oldukça

${ }^{3}$ Konuyla ilgili detaylı bilgi için bkz. http://www.kastamonu.gov.tr/halime-cavus (Son erişim: 09.01.2020). oldukça dikkat çekicidir. Ersizlerdere Kanyonu ile Karacehennem Boğazı (Küre) son birkaç yıldır çok sayıda kişiyi kendine çekmekte ve ulaşımın da kolay olması sahayı ayrıca cazip kılmaktadır. Esasında genel olarak Bat Karadeniz ve bu kapsamda da İstiklâl Yolu Tarihi Milli Parkı ve çevresi "Jeoturizm"e konu olabilecek çok sayıda değere sahiptir. Kanyonlar yanı sıra mağaralar, boğazlar ve zirveleriyle ilgilileri kendine çekebilecek büyük bir potansiyeli haizdir. Söz konusu doğal şartların altyapısını teşkil ettiği sportif faaliyetler ise bölge için ayrıca çekicilik teşkil etmektedir. Kış sporları için önemli bir merkez olan Doruk Mevkii (Çankırı / Ilgaz), Yıldıztepe Kayak Merkezi (Çankırı / Ilgaz) yanı sıra Bat Karadeniz'deki dağlık alanlar yaz döneminde de kampçılık, foto safari, kuş gözlemciliği, piknik (dumansız), orienteering, trrmanıcılık gibi etkinliklere de olanak tanımaktadır.

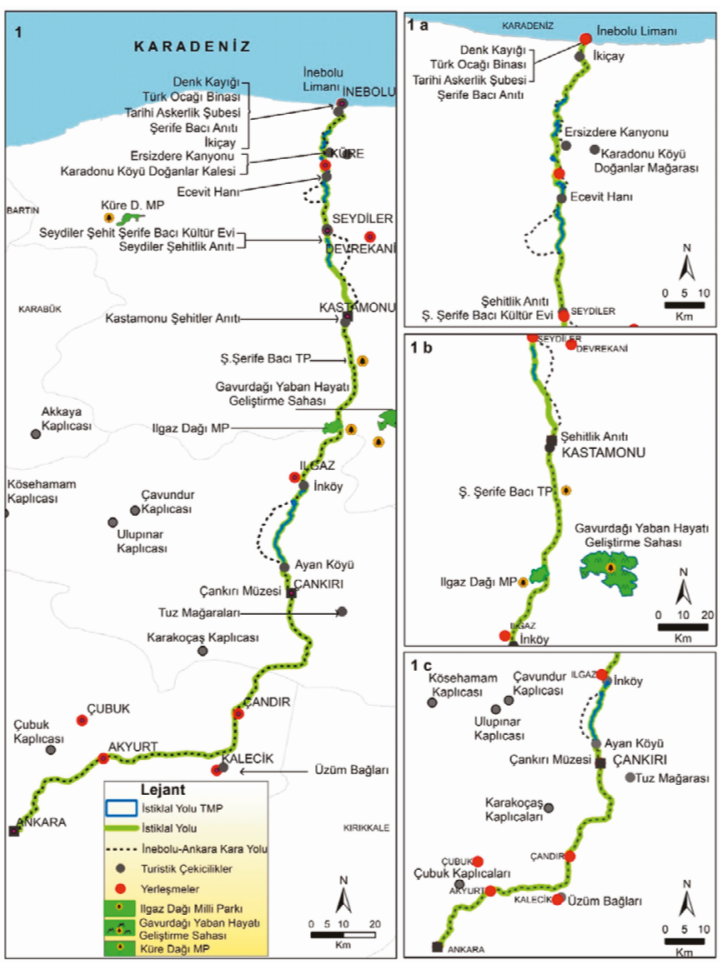

Şekil 4. İstiklâl Yolu tarihi milli parkı ve çevresinde turizme konu olabilecek destinasyonlar

Figure 4. Important tourism destinations in Istiklal Road historical National Park and surroundings

Floristik açıdan baktığımızda zaten genel olarak Bat Karadeniz bu anlamda çok büyük bir potansiyeli haizdir. Ilgaz Dağları, Türkiye'nin en önemli endemizm merkezlerinden biri olup toplam 1.055 ha. ormanlık alanı bulunan Ilgaz Dağı Milli Parkı'nda 51 familyadan 234 tür ve alttür tespit edilmiş, endemizm ise \% 15.8 gibi çok yüksek bir oranda tespit edilmiştir (Öztürk ve Aydoğdu, 2012: 619; Altundal ve ark., 2018: 322). Küre Dağları Milli Parkı da benzer şekilde floristik açıdan önemli merkezlerden birisidir.Karadeniz Nemli Karstik Ormanların en iyi örneklerinden birisi olan parkta 157 endemik tür bulunmakta olup saha aynı zamanda Avrupa'daki korunması gereken 100 Orman Sıcak Noktasından birisi olarak belirlenmiştir (Şen ve Erkan Buğday, 2015: 218). İstiklâl Yolu Tarihi Milli Parkı, çevresindeki diğer koruma sahaları ve genel manada Ilgaz Dağları ve çevresi bitki çeşitliliği yanı sıra vahşi yaşama dair önemli hayvansal varlığıyla da dikkat çekmektedir.Yöre pek çok memeli (Karaca, tilki, bozayı, vaşak, porsuk gibi) ve kuş türüne ev sahipliği yapmakta olup özel ilgi turizmi kapsamında da çok sayıda eklem bacaklının da gözlenebildiği bir alandır. Küre Dağları Milli Parkı'nda to- 
plam 129 kuş türü, 48 memeli, 23 sürüngen tespit edilmiş olup BirdLife International tarafindan da 2004'te “Türkiye'nin Önemli Kuş Alanları" listesine dahil edilmiştir". Bu iki büyük milli parktan başka yaklaşık 10 ha.'Iık bir alanı kapsayan 2011'de kurulmuş Şehit Şerife Bacı Tabiat Parkı da bir diğer destinasyon sahası olarak dikkat çekmektedir.

Esasında İstiklâl Yolu Tarihi Milli Parkı için sayılabilecek doğal çekiciliklerde burasıyla adeta iç içe olan 2 milli parkın varlığı büyük avantaj sağlamaktadır. Ilgaz Dağı Milli Parkı'nın 1.118 ha.'Iık alanının \% 69'u Kastamonu, \% 31'lik kısmı da Çankırı'da kalmaktadır. İstiklâl Yolu'nun 4 km.'si de söz konusu parkın içinden geçmektedir. Toplam 37.753 ha.'lık alanıyla Küre Dağları Milli Parkı'nın da \% 52'si Bartın'da, \% 48'i de Kastamonu'da kalmaktadır. Doğa turizmine yönelik olarak da burası da bir önceki milli parkla beraber sadece Türkiye'nin değil dünyanın en önemli doğa koruma alanlarından birini teşkil etmektedir. Bu açıdan her ne kadar tarihi milli parklar içerisinde yer alıyor olsa da İstiklâl Yolu Tarihi Milli Parkı'nın turizm planlamasında özellikle ekoturizm faaliyetlerine ilgisi olanlar için de beklentilerini karşılayabilecek olduğunun özellikle belirtilmesi gerekmektedir.

\section{b. Tarihi - Kültürel Çekicilikler:}

İstiklâl Yolu Kastamonu - Çankırı - Ankara illerini İstiklâl Yolu Tarihi Milli Parkı ise Kastamonu ve Çankırı illerini kapsamaktadır. Bu açıdan milli parkın belli bölümlerini barındıran söz konusu iki ilin diğer kültürel çekiciliklerinin de çok iyi bilinmesi ve yola paralel bir şekilde turizm açısından planlanması çok önemlidir. Adı geçen illerden ve aynı zamanda yolun başlangıç noktası olan Kastamonu; günümüzde şehrin içinden geçen Karaçomak Deresi vadisi boyunca kurulup gelişmiş, bununla birlikte ilk olarak ne zaman kurulduğu tam olarak bilinmeyen Bat Karadeniz'in önemli merkezlerinden birisidir. Geçmişi Alp Paleolitik Yontma Taş devrine kadar uzanan yörede Hitit, Frig, Helenistik, Roma ve son olarak Türk devirlerine ait çok sayıda kalınt bulunmaktadır (Şahin, 2001: 585). Kastamonu, Beylikler Dönemi'nde başkent, Osmanlı İmparatorluğu döneminde de Eyalet Merkezi olmuş olan önemli bir merkezdir.

Esasında İstiklâl Yolu denildiğinde Kastamonu'dan önce İnebolu kenti ve limanı akla ilk gelen noktadır. Çekiciliklerin başında yaz mevsiminde denizi, bugün çok az sayıda kalan ahşap mimarisinin en güzel örnekleri olan evler ve daha önce açıklanan cephanelerin taşınmasında gösterdikleri fedakarlıklar sonucu TBMM tarafindan İstiklâl Madalyası ile onurlandırılan İnebolu ilçesi gelmektedir. Kuruluş tarihi kesin olarak belli olmayan ilçe, İkiçay Deresi'nin Karadeniz'e döküldüğü yerde Miletliler tarafindan kurulan bir kolonidir (Fakazlı, 2006: 2). İlk yerleşim yeri bugünkü Boyranaltı mevkiidir. İnebolu, Candaroğulları Beyliği zamanında Türk hakimiyetine geçmiş ve ondan sonra da işgale uğramamıştır. İlçe, 1870 yılında belediyenin kurulmasıyla kaza olmuş, 1880 ve 1885 yıllarında iki büyük yangın geçirmiştir. Kastamonu Valisi Abdurrahman Paşa tarafindan bir İtalyan mimara çizdirilen kare planlı taştan modern bir çarşı inşa edilmiştir.

İnebolu'nun Kurtuluş Savaşı'nda gösterdiği kahramanlıktan dolayı Atatürk, 1 haftalık Kastamonu gezisinde 3 gününü buraya

${ }^{4}$ Detaylı bilgi için bkz. https://www.kdmp.gov.tr/ (Son erişim: 02.01.2020). ayırmıştir. 25 Ağustos 1925 tarihinde öğleden sonra Kastamonu'dan İnebolu'ya hareket etmiştir. 26 Ağustos günü Mareşal üniformasıyla belediye binasına gelerek kahraman İnebolulu kayıkçıları ve çeşitli heyetleri kabul etmiş, Kurtuluş Savaşı'nda gösterdikleri emeklerden dolayı övgü dolu sözler söylemiştir. 27 Ağustos günü Ulu Önder üzerinde sivil elbisesi ve elinde şapkası ile Türk Ocağı Binası'nın balkonundan “Efendiler, bu serpuşun ismine şapka denir..." diyerek Şapka ve Kıyafet İnkılâbı'nın ilk nutkunu İnebolu'da vermiştir. İnebolu'da Gazi Paşa'nın kıyafet devrimini başlatmasıyla ilgili tarihi nutkunu verdiği Türk Ocağı Binası, onarılarak "Istiklâl Yolu Müzesi" haline getirilmiştir. Londra'daki Madame Tussauds Müzesi (Madam Tuso)'nden sonra Eskişehir Büyükşehir Belediye Başkanı Prof. Dr. Yılmaz Büyükerşen tarafindan Atatürk'ün mumdan 2. heykeliyapılarak bu müzeye armağan etmiştir. Günümüzde İnebolu'da 2 tane müze vardır. İkinci müze de belediye müzesi olup burada da Kurtuluş Savaşı ile ilgili etnografik eserler bulunmaktadır.

Kastamonu ve özelde de İnebolu haricinde milli parkın bir bölümünün sınırları dahilinde kaldığı Çankırı'yı ele aldığımızda il, günümüzde kente de adını vermiş olan Karatekin tepesindeki Çankırı / Gangra Kalesi merkezli olacak şekilde gelişmiş, Hitit, Paflagonya, Pontus, Roma, Selçuklular ve Osmanlı dönemlerinden izler taşıyan köklü bir medeniyet geçmişi bulunmaktadır (Şahin, 1993: 216). Çalışma konumuz olan İstiklâl Yolu Tarihi Milli Parkı'nın da önemli bir kısmının sınırları dahilinde kalan Çankırı, özellikle alternatif turizm faaliyetleri bakımından önemli bir potansiyeli haiz olsa da ne yazık ki genel manada turizm açısından geri kalmış illerden birisidir. Bu noktada bahis konusu milli park vasıtasıyla ilin diğer çekiciliklerinin de tanınırlığı konusunda kayda değer bir başarı elde edilebileceğini söyleyebiliriz.

İstiklâl Yolu Tarihi Milli Parkı'nın sınırları dahilinde kaldığı merkezlerin her birinin köklü geçmişi, kültür turizmine yönelik çok sayıda değeri haiz olmalarına imkan tanımıştır. Örneğin sadece Çankırı'da 230 adet kültür varlığı bulunmaktadır (Kuter, 2007: 74). Milli park özelindeki kültürel değerlere baktığımızda ise bunlardan ilki İnebolu'da yolun başlangıcında bulunan ve ne yazık ki bugün harabe halindeki eski Askerlik Şubesi'dir. Bunun dışında yol üzerinde sağlam kalmış eski yol, menfez ve taş köprülerin bir kısmı ayaktadır. Yolun sonundaki Ankara MKE Masam Fabrikası yakınındaki Tüney Jandarma Karakolu ${ }^{5}$ 'nun da bir kısmı yıkılmış durumdadır. Milli Mücadele süresince gerek yolcular gerekse mühimmat taşıyanların geceledikleri 27 han yıkılmış durumdadır. Bunlardan Ecevit Hanı'nın yeri değiştirilerek yeniden yapılmıştır. Yine Ilgaz Derbent Şehitler Anıtı ve Kastamonu Şehitler Anıt bu yolla ilgili yapıtların başlıcalarıdır.

Hüzün veya Kara Turizm olarak adlandırılan ve son yıllarda tüm dünyada turizm kapsamı içerisinde önemi artan bu konu özellikle tarihte yaşanmış acılı, kanlı, dramatik olayların hatırda tutulması noktasında turizme konu edilmesiyle ortaya çıkmıştır. Bu noktada da İstiklâl Yolu Tarihi Milli Parkı ve Kastamonu çok özel bir yer işgal etmektedir. Çanakkale ve Kurtuluş Savaşlarında en fazla şehit veren illerden birisi olan Kastamonu (Özellikle de Ersizlerdere'de yaşanan olağanüstü durum gibi), aynı zamanda lojistik manada da stratejik bir rol oynamıştr. Ayrıca Milli Mücdele'nin diriliş simgesi olan ilk kadınlar mitingi (10 Aralık 1919)

${ }^{5}$ Tüney Jandarma Karakol Binası ve bahçesiyle birlikte Mayıs 2019 itibariyle ihaleye çıkartılarak satışı yapılacak emlak listesine dahil edilmiştir. 
Kastamonu'da gerçekleşmiştir. İstiklâl Yolu Tarihi Milli Parkı ise Hüzün Turizmi kapsamında öne çıkartllacak güzergahlardan birisidir. Gelibolu'ya her yıl Anzak askerlerini anmak ve yaşanan olayları yerinde görmek için gelen binlerce Avustralyalı ve Yeni Zelandalı turist; her yıl düzenlenen Sarıkamış şehitlerini anmak için yapılan Kars - Sarıkamış Anma Yürüyüşü gibi etkinliklerde olduğu şekliyle İstiklâl Yolu Tarihi Milli Parkı da bu örneklerdeki gibi dikkat çekilebilecek noktalardan birisidir.

Çankırı doğal ve kültürel çekiciliklerinin fazlaca tanıtılamaması ve turizm altyapısının çok gelişmemiş olduğu bir yer olması dolayısıyla bu açıdan yapılması gereken çok sayıda yatırım söz konusudur. Karatekin tepesindeki Bizans dönemine ait kalıntlar ile kaya mezarları, Emir Karatekin Bey Türbesi ile önemli bir çekicilik sahasıdır. Yakın yıllarda çevresinin mesire alanı olarak düzenlenmiş olması ile birlikte sahanın Bizans ve diğer medeniyetlere ait kalıntllarla bir nevi açık hava müzesi haline getirilip İstiklâl Yolu Tarihi Milli Parkı konusunda da tanıtıcı pano ve heykellerle bütünleştirilmesi önerilebilir. Böylece ziyaretçiler için Çankırı'da önemli bir istirahat ve alışveriş noktası olabilecektir. Milli park ziyaretçileri için Çankırı'daki bir diğer önemli destinasyon sahası da kaya tuzu mağaralarıdır. Çankırı il merkezine 22 km. uzaklıktaki Balıbağı köyündeki kaya tuzu mağaraları bu anlamda öne çıkartılabilecek mekanlardandır. Son yıllarda klinik - terapi merkezi olarak dünyanın birkaç yerinde (Avusturya - Salzburg / Hallein; Almanya - Magdeburg gibi) hizmet veren tuz mağaralarında bronşial astım hastalarının 6 ay ila 3 yıl gibi sürelerde rahatsızlığın etkilerinden kurtuldukları gözlenmiştir (Halilova, 2008: 166). Sağlık turizmi kapsamında tuz mağaraları yanı sıra Çankırı'da çok sayıda termal bulunmakta olup bunların bir kısmı modern tesislerle turizme yönelik düzenlenmiştir. Özellikle ilin kuzeyinde batıdan doğuya doğru Çerkeş - Atkaracalar - Kurşunlu - Ilgaz hattında çok sayıda termal kaynak bulunmakta olup bunlardan Çavundur, Karacaviran, Kös, Acısu ve Kazancı kaplıcaları en popüler olanlarıdır.

Son dönemlerde turizm konusu içerisinde üzerinde en fazla durulan konulardan biri de turistik ürünlerdir. Özellikle yerel ekonomi başta olmak üzere kadın işgücüne dayalı ürünler ve büyük pazarlara erişim olanağı bulunamayan ya da güç olan ürünler için bu durum çok önemlidir. Bunun yanı sıra yine son dönemlerin en popüler konularından biri olan coğrafi işaret kapsamındaki ürünlerin de turizm faaliyetleri kapsamında öne çıkartılması bir diğer göz önüne alınması gereken noktalardandır. Bu kapsamda İstiklâl Yolu Tarihi Milli Parkı güzergâhı boyunca yerel, coğrafi işaret niteliğinde olan karakteristik ürünlerin pazarlanması hususuna da dikkat çekilmesi gerekir. Bu grupta değerlendirilebilecek ürünler ise; Evrenye Bıçağı, Inebolu Kızılcık Tarhanası, Azdavay Bebeği, Küre Kilimi, Kastamonu Siyez Bulguru, Kastamonu Kestane Balı, Cide Sarı Yazması, Çankırı Kaya Tuzu daha uzak noktalardan yol boyunca çeşitli durak noktalarında pazarlanabilecek Tosya Pirinci, Tosya Bıçkısı, Çatalzeytin Fındık Şekeri, Taşköprü Sarımsağı sayılabilecek ürünlerden birkaçıdır (Şahin, 2019: 2008-2029). Söz konusu ürünlerin kolaylıkla uzak mesafelere taşınabilir olması, turistlerin yanlarında taşımada fazla zorlanmayacağı nitelikte olmaları dikkat çekilmesi gereken bir husustur. Nitekim Kapadokya gibi önemli bir turizm cazibe merkezine yakınlığıyla tanınırlığı yurtdışını aşan Soğanlı Bez Bebekleri ile yine turizme bağlı olarak pazar payı genişleyen Sürmene Bıçakları'na benzer durum yöre ürünleri için de düşünülebilir.
Turistlerce beraberlerinde götürülebilecek ürünler dışında yanlarında götüremeyecekleri fakat ilgililerce büyük alaka gösterilen yeme - içme kültürüne ait değerler de İstiklâl Yolu Tarihi Milli Parkı için düşünülmesi gereken bir diğer noktadır. Gastroturizm kapsamında değerlendirilebilecek yörenin zengin mutfağından elemanların, yine belli başlı duraklarda ziyaretçilere sunulması çok önemlidir. Gerçekten de özellikle Kastamonu Mutfağı gibi çok zengin, buna karşılık çoğu yerel mutfağın aksine gerektiği gibi tanıtılamamış bir mutfağın bu sayede daha çok kişiye ulaştırılması olanağı sağlanacaktır. Banduma, etli ekmek, pastırma, tirit, kuyu kebabı, Küre mantısı, cırık tatlısı, Çankırı yumurta tatlısı gibi sayısı artırılabilecek çok sayıda karakteristik yemek bu anlamda öne çıkartılmalıdır. Söz konusu yemeklerin büyük bir kısmı günümüzde ya coğrafi işaret kapsamına alınmış ya da başvurusu yapılmıştır. Özellikle de İstiklâl Yolu Tarihi Milli Parkı için önemli durak noktalarından biri olan ve restore edilmiş han (Ecevit Hanı) ile aynı adı taşıyan Ecevit Çorbası ziyaretçilerin beğenisine sunulmalıdır.

Ziyaretçilerin turistik ürünleri alabileceği, yöre mutfaklarından elemanları tada bilecekleri durak yerlerinde, turistlerin hoş vakit geçirmesi adına çeşitli folklorik değerlerin gösterilmesi de diğer bir çekicilik olarak öne çıkartılmalıdır. Bu noktada yolun başlangıç noktası kabul edilen İnebolu'da, yöre folklorunun önemli bir parçası olan "Heyamola”, İnebolu'daki gemicilik geleneğinin bir parçası olarak günümüzde hala, özellikle özel günlerde sürdürülen bir etkinlik olarak devam etmektedir. Çankırı'da ise Yaren / Yaran Geceleri adı verilen mahalli kıyafetlerle düzenlenen ve pek çok ritüeli barındıran etkinlik de yine öne çıkartlabilecek etkinliklerdendir.

\section{Sonuç ve Öneriler}

Milli parklar başlangıçta ekolojik kaygılarla ortaya çıkmışsa da sonrasında çok kompleks koruma alanları halini almışlardır. Nitekim çalışma konumuz olan İstiklâl Yolu Tarihi Milli Parkı da buna en güncel örneklerden biridir. Park henüz çok yeni olduğu için birtakım çalışmaların yapılması gerekmektedir. Bu yapılırken de yolun sadece hoş vakit geçirmek gibi salt turistik kaygılarla değil ziyaretçilerde bir farkındalık oluşturarak milli değerlere saygı ve bilincin artırılmasına da özen gösterilmesi gerekmektedir. Örneğin; İnebolu iki defa düşman saldırısına maruz kalmasına rağmen kadını, yaşlıları ile çektiği acılara rağmen cepheyi cephanesiz bırakmamıştır. O günleri hatırlatmak, iyi yorumlamak ve bunları gelecek nesillere aktarmak zorunda olduğumuzun altını çizmek gerekir.

Milli parklar o bölgede, tabii her şeyiyle korumak, gelecek nesillere olduğu gibi aktarmak amacıyla ilan edilmektedir. İstiklâl Yolu Tarihi Milli Parkı'nda da bundan sonraki süreçte kullanma dengesi içinde yapılaşma, restorasyon, inşa edilenlerin bakım ve onarımlarının yapılması gerekmektedir. Bunlar yapılırken de öncelikle doğal çevreye ve sonrasında da Milli Mücadele'nin en önemli merkezlerinden biri olan sahadaki tarihi dokuya saygılı olunması bir zorunluluktur. Söz konusu milli park, yeni kurulduğu için tanıtım tesisleri kurmak ve altyapı sağlamak gerekmektedir. Zira koruma ve kullanma ilişkisi içerisinde tarihi değeri ve çeşitli potansiyeli ile oluşacak turizm potansiyeline bağlı olarak turistlerin ihtiyaçlarını karşılayacak (Konaklama vs.) uygun tesislerle donatılması gerekmektedir.

İstiklâl Yolu Tarihi Milli Parkı için ilk etapta yapılması gereken- 
lerin başında birtakım kültürel değerlerin ivedi ele alınması öncelikli olmalıdır. Yörede bugün harabe haline gelmiş, savaş yıllarında çok önemli olan bazı yapıların mutlaka çok yakın bir tarihte onarılması gerekmektedir. Aksi taktirde ihmalden kaynaklı yıkımlarla geri dönüşü olmayacak sonuçlar ortaya çıkacaktır. Örneğin; İnebolu Askerlik Şubesi, Çankırı sınırları içindeki Üçoluk Karakol Binası, Ankara yakınlarında eski Askeri Fabrika Binası sayılabilir. Ayrıca zamanın depo ve durak yerleri tespit edilip buralara panoların konması, mümkünse konaklanan hanların birkaç tanesi aslına uygun olarak yeniden yapılmalıdır. Bununla ilgili olarak Ecevit Hanı eski bulunduğu yerden başka bir yerde yeniden yapılmıştır. Yolun bugün kullanılmayan Ankara Çankırı arasındaki kısmı aslına uygun olarak yeniden yapılmalı, özellikle ziyaretçilerin bu rotayı kullanması sağlanmalıdır. Tarihi yapıların restorasyonu veya aslına uygun bir şekilde yeniden yapılmasıyla birlikte buralar kültür merkezi haline getirilerek yörenin önemi hakkında tanıtıc film gösterileri ve panolarla ziyaretçilere sunumlar hazırlanmalıdır. Yine bu gibi mekanlar her yıl veya belli aralıklarla düzenlenecek tarihi kongre ve sempozyumlarda merkez olabilecek ve bu sayede yöre kongre turizmi için de bir cazibe merkezi olacaktır. Kültürel yapılar arasında peyzaj düzenlemede kağnılarla cephane taşıyan halkın heykelleri yol boyunca muhtelif yerlere konmalıdır. Aynı şekilde Şehit Şerife Bacı ve Halime Çavuş gibi milli kahramanlara ait heykel ve tanıtıcı panolar da yolun uygun yerlerine yerleştirilmelidir.

Yöredeki çeşitli imar ve restorasyon faaliyetleri sahanın doğal çekiciliklerine de yön verir özellikte olmalıdır. Ersizlerdere Kanyonu'na uygun yerlere seyir terası yapılması, oradan İkiçay Tarihi Köprüsü, Karacehennem Boğazı Kanyonu, Küre Dağları'nın muhteşem manzarasını gözlemlemek ve mola verip dinlenmek için iyi bir vesile olacaktır. Ancak orada 1899 yılında yapılan, bugün kullanılmayan iki kemerli İkiçay Tarihi Köprüsü’nün karayolları tarafindan onarılan yeni kısmı kaldırılarak eskiye uygun olarak yenilenmesi gerekmektedir. Yolun bir kısmı ziyaretçilerin arzularına bağlı olarak farklı araçlarla kat edilebilir olmalıdır. ATV, bisiklet, yaya, binek araç yanı sıra Milli Mücadele ruhunu yaşatmak adına kağnılarla harekete olanak sağlanmalıdır. Söz konusu hat, 2008'de Atatürk ve İstiklal Yolu Yürüyüşü olarak Kastamonu Valiliği'nce bir rota olarak planlanmış ve Türkiye'nin en uzun üçüncü trekking hatt olmuştur. Bu kadar uzun bir parkuru kağnılarla kat etmek ziyaretçiler için mümkün olmayacağından kısa bir mesafe kağnılar, devamı ise alternatif ulaşım araçlarıyla sağlanabilir.

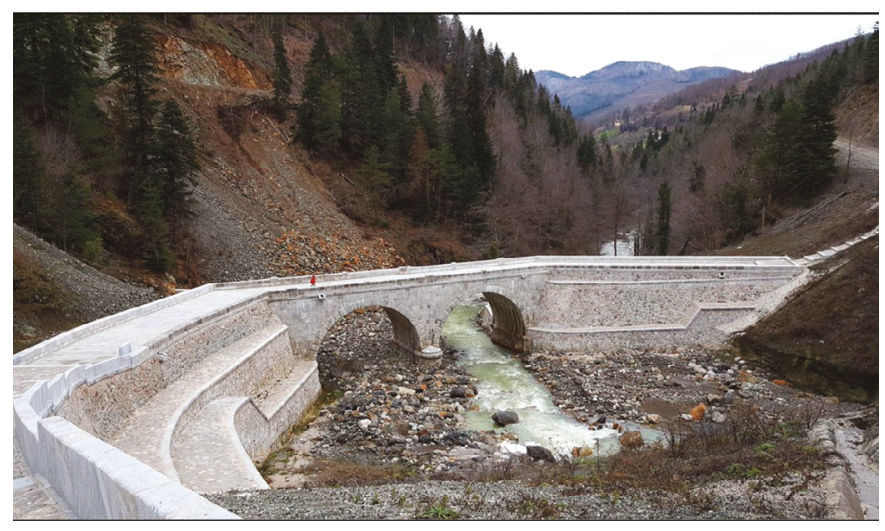

Fotoğraf 3. Tarihi İkiçay köprüsü’nün günümüzdeki hali (Savaş Cihad Meriç Arşivi)

Photograph 3. The current status of the historical Ikiçay Bridge

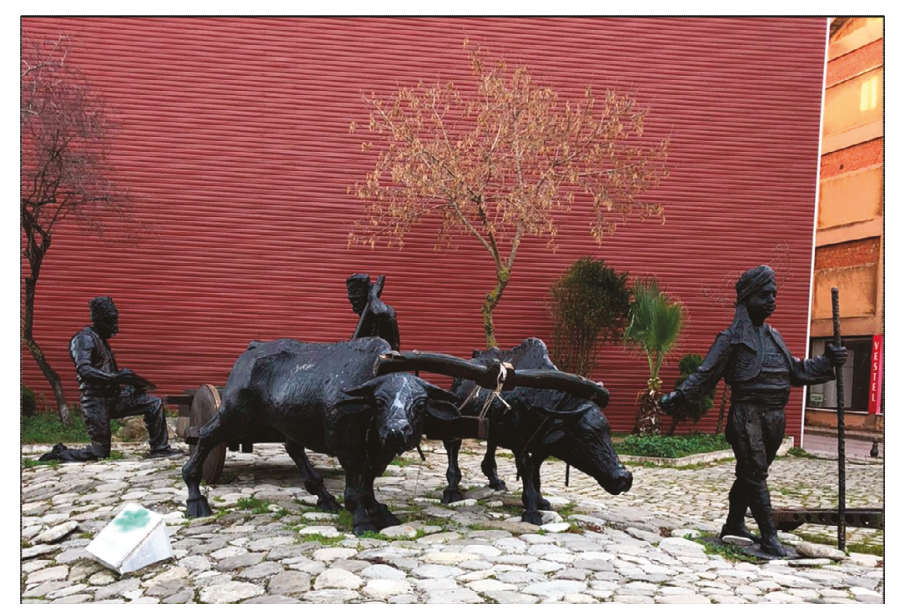

Fotoğraf 4. İnebolu'daki kağnı kollarını tasvir amaçlı yapılmış peyzaj düzenlemesi

Photo 4. Landscape arrangement depicting carts in Inebolu

İstiklâl Yolu Tarihi Milli Parkı için belirlenen rota, her yaş kitlesine uygun olacak şekilde 7-3-2 günlük turlar şeklinde planlanmalıdır. Dileyenler için kamp, dileyenler için modern konaklama tesislerinde geceleyecek şekilde farklı içerikte turlar düzenlenerek başta Çankırı gibi turizm açısından fazlaca gelişmemiş bir il için söz konusu milli parkın çekiciliği kullanılmalıdır. Ayrıca yol boyunca uygun yerlerde yerel ürünlerin tanıtilıp satışının yapıldığı yerler de milli park sınırlarındaki sınırlı yerel ekonomilere katkı sağlayacak ölçüde düzenlenmelidir.

Bugün yayın organları en iyi reklam ve tanıtım aracıdır. Bunun için TV'de bölgeyle ilgili çeşitli yayınların yapılması gerekmektedir. Ayrıca İnebolu'da yapılan çalışmalardan bahsetmek gerekir. Medya da İstiklâl Yolu en az Sarıkamış ve Gelibolu kadar yer işgal etmeli ve yerel yönetimlerce de öne çıkartılmalıdır. Örneğin; 25 Ağustos 2019'da düzenlenen 10 km.'lik yarışa 90 sporcu katılmış, ayrıca $2 \mathrm{~km}$. halk koşusu da yapılmıştır. Buna benzer bir yürüyüş de Kastamonu'da yapılmıştır. Bu ve benzeri çalışmalar yayın organlarında yer alması tarihi parkın tanıtımı için oldukça önemlidir.

\section{Kaynakça}

Altundal Öncü, M., Güney, İ., Göközkut, B., (2018). “Ilgaz Dağı Milli Parkı ve Kış Sporları Turizm Merkezinin Sürdürülebilirlik Kriterlerine Göre Değerlendirilmesi", Uluslararası Sosyal Araştrrmalar Dergisi, Cilt: 11, Sayı: 59, s. $320-328$.

Anonim, (2017). "İstiklal Yolu Tarihi Milli Parkı (Öneriler)", T.C. Orman ve Su İşleri Bakanlığı, Doğa Koruma ve Milli Parklar Genel Müdürlüğü, s. 69, Ankara.

Aydınözü, D., ỉbret, B.Ü., Aydın, M., (2012). "Kastamonu Ilgaz Dağı Milli Parkında Arazi Kullanımının Analizi", Marmara Coğrafya Dergisi, Sayı: 26, s. $108-123$, İstanbul.

Baykal, F., (2019). "Türkiye Turizm Coğrafyası”, Türkiye Beşeri ve İktisadi Coğrafyası, (Ed. Nuran Taşlıgil ve Güven Şahin), s. 349 - 421, Ankara.

Cebeci, D., (2016). “Türkiye Cumhuriyeti İnkılâp Tarihi Ve Atatürkçülük Derslerinde "istiklâl Yolu"Nun Öğretimi: (Mevcut Ders Kitapları, Öğretmen Ve Öğrenci Görüşleri Ve Çağdaş Yayınlar Işığında Yeni Bir Etkinlik Paketi Tasarımı)", Çankırı Karatekin Üniversitesi, Sosyal Bilimler Enst., Basılmamış Yüksek Lisans Tezi, s. 178, Çankırı.

Chapuis, R., Lanneaux, M.A., (1993). Annales de Geographie. No: 573, 102e, Anneeseptembre - Octobre, p. 519. 
Çiçek, R., (1997). “Ankara Hükümeti’nin Dünya'ya Açılan Kapısı İnebolu - Ankara Yolu", Atatürk Yolu Dergisi, Cilt: 5, Sayı: 20, s. 399 $-413$.

Doğanay, S., (2003). “Coğrafi Özellikleri Açısından Altındere Vadisi Milli Parkı”, Doğu Coğrafya Dergisi, Cilt: 8, Sayı: 10, s. 43 -64, Erzurum.

Dündar, A., (2005). “Çankırı'daki Türk İslam Yapıları”, Geçmişten Geleceğe Çankırı, Çankırı Valiliği III. Çankırı Kültürü Bilgi Şöleni Bildirileri, $28-29$ Eylül 2005, s. $245-272$.

Eğdirici, N., (2014). "Beşik", Şahsi Baskı, İnebolu Yardımlaşma ve Dayanışma Derneği'ne Armağan, s. 80, Ankara.

Eski, M., (1997), "Inebolu Limanının Tarihçesi ve Önemi”, Atatürk Araştırma Merkezi Dergisi, Sayı: 39, Cilt: XIII, Kasım 1997, s. 929 - 940, Ankara.

Fakazlı, M.S., (2006). “9 Haziran'dan Bugüne 'Inebolu'”, Yeni İnebolu Ofset, s. 79, inebolu.

Gürsoy, C.R., (1975). “Türkiye'nin Tabiî Yolları”, Türk Coğrafya Dergisi, Cumhuriyetimizin 50. Yıl Özel Sayısı, Sayı: 26, s. $24-33$, İstanbul.

Halilova, H., (2008). “Çankırı Tuz Mağarası ile Kaplıcaların Sağlık Üzerine Etkileri”, 100. Yıla Doğru Çankırı - Çankırı Valiliği IV. Çankırı Kültürü Bilgi şöleni Bildirileri, 13 - 15 Kasım 2008, 165 170, Ankara.

ibret, B. Ü., Aydınözü, D., Bekdaş, F., (2010). “Karadeniz Kıyısında Stratejik Bir Liman: İnebolu Limanı”, İstanbul Üniversitesi Edebiyat Fakültesi Coğrafya Bölümü - Coğrafya Dergisi, Sayı: 20, s. 15 -33 , İstanbul.

Kuter, N., (2007). "Çankırı Kenti Ve Çevresinin Turizm Açısından Değerlendirilmesi", ZKÜ Bartn Orman Fakültesi Dergisi, Cilt: 9, Sayı: 11, s. $71-77$.

Öztürk, S., Aydoğdu, A., (2012). “Ilgaz Dağı Milli Parkı'nın Rekreasyonel Olanakları", I. Rekreasyon Araştırmaları Kongresi, 12 - 15 Nisan 2012, s. 611 - 628, Antalya.

Palaşoğlu, E., (1985). “Milli Parklar Dairesi Başkanlığı Çalışmalarının Önemi, Gelişimi ve Kanuni Mevzuat", Milli Parklar ve Yaban Hayat Semineri -1985, s. 16, Muğla.

Resmi Gazete, (2018). https://www.resmigazete.gov.tr/eskiler/2018/11/201811027.pdf (Son erişim: 22.10.2019).

Şahin, G., (2019). Türkiye'nin Coğrafi İ̧̧aretleri ve Bunların Türkiye Ekonomisinde Etkin Kullanımları, İstanbul Üniversitesi Sosyal Bilimler Enstitüsü, Basılmamış Doktora Tezi, s. 2551, İstanbul.

Şahin, i., (1993). “Çankııı”, İslam Ansiklopedisi, Cilt: 8, s. 216 - 218, istanbul.

Şahin, i., (2001). "Kastamonu", İslam Ansiklopedisi, Cilt: 24, s. 585 588 , İstanbul.

Şen, G., Erkan Buğday, S., (2015). "Kastamonu Illinde Çeşitli Statülerde Koruma ve Kullanma Amaçlı Belirlenmiş Alanlar", Kastamonu Üniv., Orman Fakültesi Dergisi, 15 (2), s. 214 - 230, Kastamonu.

Taşlıgil, N., (1994). “Spil Dağı Milli Parkı”, Türk Coğrafya Dergisi, Sayı: 29, s. $257-268$.

Taşlıgil, N., (2010). "Türkiye'nin Ulaşım Coğrafyası”, Çantay Kitabevi, II. Baskı, s. 224, ISBN: 978-975-9060-76-3.

T.C. Çevre ve Şehircilik Bakanlığı, Doğa Koruma ve Milli Parklar Genel Müdürlüğü: http://www.milliparklar.gov.tr/ (Son erişim: 22.10.2019).

Yılmaz, İ., (1989). "Milli Mücadelede Ulaşım”, Atatürk Dergisi, Cilt: 1, Sayı: 3, s. $101-120$, Erzurum.

\section{İnternet Kaynakları}

http://www.kastamonugazetesi.com.tr/ionopolisten-ineboluya/ https://cultureroutesinturkey.com/tr/istiklal-yolu/ https://cankiri.ktb.gov.tr/TR-70695/yildiztepe-turizm-merkezi.html http://www.kastamonu.gov.tr/ilgaz-dagi-milli-parki-kis-sezonu-hazirlik-toplantisi-yapildi https://www.kdmp.gov.tr/kdmp-hakkinda/kure-daglari-milli-parki 